\title{
A 3D Approach to Security and Development
}

\section{Robbert Gabriëlse *}

\section{Introduction}

There is an emerging consensus among policy makers and scholars on the need for a more integrated approach to security and development policies in post-conflict regions. That notion was shared during the conference entitled 'A Comprehensive Approach to Modern Conflict: Afghanistan and Beyond,' hosted by the George Marshall Center on March 26th and 27th, 2007. Distinguished academics, policy makers and representatives form international governments shared their views and experiences. This article is based on a short introduction I gave during that conference, having the privilege to be in one of the panels. Drawn upon the experiences of the Netherlands in different missions, recently in Southern Afghanistan, we believe interagency cooperation goes hand in hand with an integrated approach on the ground. Furthermore, cooperation with other governmental and non-governmental organizations, national as well as international, is crucial to succeed. Success can only be established in terms of strengthening local ownership. Therefore, a comprehensive approach should be aimed at strengthening the national and regional institutions. We all learn from our experiences and only by sharing this knowledge we can improve our policies. There is however no 'one size fits all' solution and there are no easy fixes. Every mission and every situation will require its own approach. We should be open for continuous adaptation and change in our strategies and policies.

\section{A 3D, Comprehensive Approach}

In recent decades the international community has been engaged in a variety of postconflict programs and missions aimed at improving the security situation and promoting sustainable development. These activities include the establishment of rule of law, building up the security sector, setting up good governance, providing economic assistance, restoration of governmental services (like education, health), etc. All these activities are a concerted effort to support reconstruction and preventing post-conflict countries from sliding back to war. In countries emerging out of conflict, reconstruction activities are often hampered to a considerable extend by non-state actors and spoilers who seek to undermine reconstruction and democracy. Counterinsurgency has increasingly become a significant component of post-conflict reconstruction.

These recent experiences and insights have resulted in a growing consensus for increased synergy between Defense, Diplomacy and Development (3D) in post conflict and counterinsurgency situations.

A variety of terms are in use, '3D approach,' 'comprehensive approach,' 'whole of government approach' etc., but they all encompass the notion that reconstruction ef-

Mr. Robbert Gabriëlse is Director for Conflict Prevention, Ministry of Foreign Affairs, The Netherlands. 
forts and counterinsurgency operations in a post-conflict situation are intertwined and cannot be approached separately. They require an integrated approach. This means that military, diplomatic and development efforts need to be integrated as much as possible to achieve the ultimate goal: the strengthening of local institutional capacity. Thus the international community is confronted with a complex challenge. On the one hand, there is a necessity for the international community to support post-conflict countries and the reconstruction process. And on the other hand this means that donor countries have to give careful thought to setting up an integrated strategic planning. Post-conflict reconstruction support requires a 'unity of effort' and thorough interdepartmental cooperation of the donor countries involved. The aim is 'as civil as possible and as military where necessary.' The military as a rule will not conduct reconstruction activities.

Improving interagency cooperation is currently on the agenda in many different organizations. In December 2006 the US Army Headquarters published a counter insurgency manual, taking a comprehensive approach to counterinsurgency operations. General Petraeus, currently the commander of US forces in Iraq, helped oversee the drafting of this manual, which puts great emphasis on civilian-military cooperation. The recent publication Whole of Government Approach in Fragile States, from the Organization for Economic Co-operation and Development (OECD) stresses the importance of greater coherence between security and development policies in fragile states, and encourages a more joined-up approach of international actors. After the Riga summit of 28 and 29 November 2006, NATO announced its intend to further develop on a Comprehensive Approach policy, acknowledging the need for interagency-cooperation in NATO activities.

\section{Afghanistan}

Together with our partners, the Netherlands follows a comprehensive approach as part of the ISAF mission in Southern Afghanistan. At the base of this approach lies the conviction that security and stability are necessary preconditions for sustainable development in Afghanistan. It is a three D mission: it encompasses Defense, Diplomacy and Development, setting conditions for reconstruction. In Defense, the emphasis is on stability through assisting the Afghan government in developing its own security institutions. Diplomacy is aimed at improving the local, regional and national government and preventing conflicts. Development is directed at improving the socio-economic perspectives for the local population. This requires a joint effort by development experts, diplomats and the military with a common preparation, common analytical framework (civil assessment) and common presence on the ground.

With 2000 military the Netherlands is the sixth largest NATO contributor to ISAF. Since 1 August 2006 a Provincial Reconstruction Team and Battlegroup have been deployed in Uruzgan. The 'A' in ISAF stands for 'assistance' force; the aim of ISAF is assisting provincial and central government to create a stable and secure environment in which effective governance can be restored. To achieve this, so-called 'ink blots' or 'oil spots' (Afghan Development Zones) are created. These ink blots are growing at a steady pace, with the help of the Afghan National Security Forces for consolidation. At present the Dutch-Australian PRT is reaching about $60 \%$ of the population of the prov- 
ince, and we envisage to increase this to $70 \%$ by August 2008. We concentrate our military and development efforts there, whilst not forgetting to reach out to tribal leaders in outer areas.

One of the most important aspects of our efforts in Uruzgan is winning the hearts and minds of the population by working 'as civilian as possible and as military as necessary.' Strong kinetic military actions when needed, but the focus is on engaging local and tribal leaders and work on development. It is not about fighting, winning and establishing a new order. This is about being tough on opposing militant forces and at the same time convincing the people of Southern Afghanistan that after so many years of conflict, a democratically organized state is possible, and can deliver peace and stability.

Besides the military, civil representatives, political advisors, a tribal advisor and development advisors are working in the mission. A development budget for Afghanistan of more than $€ 70$ million is available. There are close contacts with tribal leaders, informing them of our activities, consulting with them regarding development initiatives and to obtain information from them regarding opposing militant forces.

\section{Strategy}

The current strategy of the Netherlands for reconstruction contains both a top-down and a bottom up approach. Top down: we channel the larger part (two-thirds) of our yearly development aid through trust funds and multilateral programs that aim at creating preconditions of good governance. The aim is an effective roll out of national and local programs as well as the increase of legitimacy of the government. Bottom up: because of the poor implementation capacity in Uruzgan, we try to create the preconditions for national programs to be rolled out. We do this by actively involving local NGOs and by directly funding projects in the sectors of education, infrastructure, health and alternative livelihoods.

In Southern Afghanistan as a whole we work closely together with our allies (UK, US and Canada) by rotating regional command, conducting larger scale operations together and providing assistance (air support) where needed. The intention is to form a composite HQRC South from February 2008.

On a political level, the ministers who are directly involved work closely together: in March this year the three newly appointed ministers for Foreign Affairs, Defense and Development Cooperation jointly visited Afghanistan as one of their first official international visits.

National interagency coordination is also very intense; on a daily basis at working level, on weekly basis on the level CHOD/Director General, MFA/diplomatic advisor to the Prime Minister. In this way we try to avoid stovepipes in which separate policies are being created. Furthermore, our embassy in Kabul plays an important role as trait d'union between national government, international organizations, PRT, civil representatives and The Hague. At different levels we keep in close contact with development organizations/NGOs. 


\section{The challenges of 3D in Afghanistan}

In shaping a 3D policy in Afghanistan, we are also confronted with a number of dilemmas. These include the relationship between security and reconstruction, central government and tribal structures, Afghan ownership and international demands. Furthermore, low absorption capacity and an underdeveloped administrative system make sustainable development a long-term process. The security situation is of vital importance to reconstruction activities. Therefore the aim is to further strengthen the Afghan security organizations. The Afghan National Army (ANA) comprises about 16,000 personnel, while ISAF in total has 35,000 troops on the ground. Consequently security in Southern Afghanistan still largely depends on ISAF troops. The pace at which the Afghan National Security Forces - both ANA and ANP (Afghan National Police)—are built up could be improved. This will enhance the inkblot strategy.

Developing the capacity of the local and national government to deliver basic services is crucial for the government's outreach to its population. It is also a prerequisite for the tribal structures to improve the confidence in their elected leaders. In Uruzgan we are in constant dialogue with the governor and the provincial ministers. Assistance is given for the creation of a provincial development plan, regular meetings of the Provincial Development Council are attended and training is provided for those involved in basic management skills (such as agenda setting, how to conduct a meeting, etc.).

Afghan ownership is a prerequisite for the sustainability of the assistance. Despite limited capacity of the Afghan government, in the long run Afghan leadership is the only solution. At the same time quick and visible results are required to give the population an interest in stability and confidence that the government will improve their living conditions.

\section{Recommendations for Increased Synergy between Defense, Diplomacy and Development}

In January of this year the Netherlands Ministry of Foreign Affairs, in cooperation with the Center for European Reform, organized a seminar with representatives of national and international organizations leading to the so called Rotterdam Recommendations. In these recommendations, the way forward to obtain true synergy between Defense, Diplomacy and Development is indicated. Consensus was reached regarding the following recommendations:

Agree on strategy: It is vital for partners-whether national governments or international organizations - to agree on joined-up strategies based on common goals. The shared goals of increasing security and sustaining development go hand in hand, and one cannot exist without the other. Ultimately, security and development policies should serve to create the conditions for peaceful politics to flourish, and this should guide strategy from the outset.

Integrate planning: Integrated planning between defense, foreign affairs and development ministries is crucial for the success of joined-up operations. Different governments and international organizations each have their own ways of integrating their 
planning procedures, particularly for operations. But in general, integrated strategic planning should be politically led from the highest level of authority.

Strive for flexibility regarding personnel and funding: More secondment of staff between different ministries and international organizations can greatly help to develop shared understanding of the synergy between defense, diplomacy and development. In addition, synergy can be improved by making political and development advisors cooperate closely with military commanders in the field, and by joint training of personnel from different departments. To support synergetic action, financial instruments need to be flexible in their setup and quickly disbursable.

Exchange lessons learned: Governments and international organizations usually undertake 'lessons learned' exercises after their operations (whether military or civil). Understandably, some of the information contained in these exercises is sensitive. However-wherever possible-government agencies and international organizations should share the lessons they have learned from their operations with each other.

Be as civilian as possible and as military as necessary: In the wide range from Civil-Military Cooperation (CIMIC) to facilitating reconstruction work by civilian organizations, soldiers today are called upon to perform non-military tasks, such as constructing schools and bridges. Although civilian actors are better placed for these tasks, sometimes conditions are such that only military actors can do the job. In general, governments should make a principle of using civilian actors as much as possible, and military forces only when necessary.

Diversify civilian input: 'Defense, diplomacy and development' do not cover all aspects of crisis management: the police, the judiciary and a wide range of other civilian expertise, from both governmental and non-governmental organizations, should also be an integral part of the planning process and of missions in the field. Policymakers should strive to share more information with these actors and to improve consultation and cooperation with them.

Strive for complementarity between international organizations: Organizations like the UN, the EU, NATO and the World Bank all have complementary resources that are useful for joined-up operations. NATO, for instance, is a military alliance, whereas the EU has diplomatic, development and military resources. Even though many organizations have already successfully worked together in joined-up operations, they should work harder to share their ideas on how to bring their resources together.

Engage in conflict prevention: Much of the emphasis in bringing together defense, diplomacy and development policies has been on post-conflict reconstruction. For a meaningful contribution to international security, policymakers should also find ways to jointly engage more proactively in preventive measures. International policies in this regard should aim to contribute to a secure and sustainable livelihood for the poor. These efforts range from addressing root causes of potential conflict and strengthening socioeconomic development to supporting reform of the security sector. Non-governmental organizations play an indispensable role in this. 
Step up public diplomacy: There are two aspects to public diplomacy that governments and international organizations should take into account. One is winning the 'hearts and minds' of the local population, crucial for the success of any joined-up operation. The other is that governments must ensure their own populations are kept informed about their operations abroad - and the joined-up nature of those missionssince public awareness is vital for sustaining political support for these missions.

Avoid stovepipes: Improving cooperation between defense, diplomacy and development is currently on the agenda in many different international organizations, with a variety of parallel processes as a result: the 'Integrated Missions Planning Process,' the 'Comprehensive Planning and Action' and the 'Whole of Government Approach.' To avoid stovepipes, these processes should be linked up and a shared set of definitions should be agreed upon. The recommendations at hand aim to serve as a catalyst for linking up these parallel tracks.

By listing and tabling these recommendations in all the different multilateral organizations involved, we hope that all those involved in this comprehensive approach start 'singing from the same hymn sheet.'

\section{Interagency cooperation in the Netherlands}

Striving for 3D synergy does not solely apply to the field of operations. Another dimension of a 3D approach is the close cooperation between the different departments and ministries concerned with defense, development and diplomacy related issues. We have not created an overarching interagency post-conflict reconstruction unit like in the UK. The focus is on interagency cooperation. In the Netherlands we try the avoid "stovepipes" through interagency cooperation at different levels.

At the political level the Ministers of Foreign Affairs, Defense and Development Cooperation work closely together. Letters to Parliament on the Netherlands contribution to international stabilization and reconstruction efforts are in most cases sent by all three ministers. During parliamentary debates on these policies the government is represented by these three ministers. In case of major decisions the Prime Minister can also take part in a parliamentary debate. This procedure stems from a constitutional requirement to inform Parliament in advance and as extensively as possible on the sending of military units abroad. In cases of sending civil experts for civilian missions (civil police, rule of law experts, administrative experts etc.) other ministers and ministries are also involved in the decision-making process.

At the policy-making level, high level interagency bodies are created between the relevant ministries. The General Affairs Ministry is involved as well as the ministries of Justice and Home Affairs. At the level of Chief of Defense and Director General weekly meetings take place and at directors level on a monthly basis. At working level there are daily contacts including the presence of a policy officer from the Ministry of Foreign Affairs in the daily briefings on running missions at the Directorate of Operations at the Ministry of Defense. Moreover, there is an exchange of military personnel and policy officers from Foreign Affairs. 
Within peacekeeping operations, civil experts work closely together with the military. At the moment the Netherlands has political, civil, tribal and development advisors working in the Netherlands-Australian Provincial Reconstruction Team (PRT). Furthermore the Netherlands has created a so-called Stability Fund, comprising $€ 100$ million per annum, in order to fund activities in the field of peace and security in developing countries. This fund enables a rapid, targeted deployment of financial resources and is therefore a valuable addition to the other foreign and development policy instruments.

The Stability Fund supports activities that aim to create a stable and safe environment as soon as possible in conflict and former conflict regions. Where there is security, people can go about their daily lives, they can work and children can go to school. This allows them to develop and creates the conditions for fighting poverty.

\section{Conclusion}

There is growing international consensus on the need for comprehensive approaches in conflict and post-conflict situations. In policy making and policy implementation there is a trend towards increased synergy between Defense, Diplomacy and Development, the so-called 3D approach. Some general recommendations have been formulated which could be the basis for further international discussion and cooperation. This approach is therefore under construction and continuously being reviewed based on 'lessons learned' from programs and missions like the PRTs in Afghanistan. There is not, however, a 'one size fits all' model, and there are no easy fixes. Long term commitment of the international community is needed to support the local and national authorities to strengthen their capacities. Local capacity building and local ownership are the ultimate exit strategies. In Afghanistan the international community together with the Afghan authorities are working on an integrated approach. We are not yet in a position to review this approach. Some initial 'lessons learned' are, cautiously, being discussed. Whether the approach in Afghanistan will be successful in the end can not be concluded yet. The challenges and the tasks ahead are difficult. Perseverance is needed to achieve a stable and secure Afghanistan. 